\title{
Támogató Bálint-csoport demenciával élő családtagot gondozó hozzátartozók számára
}

\section{Pék Győző - Kosztáné Hadházi Tünde - Orbánné Gellén Marianna - Tóthné Görög Edit - Nagy Lajosné}

\author{
PÉK GYőző: Debreceni Egyetem BTK Pszichológiai Intézet - viktorbaker55@gmail.com \\ KosZTÁNÉ HADHÁZI TÜNDE: DMJV Város Szociális Szolgálat - tünde.hadhazi@gmail.com \\ ORBÁNNÉ GelLÉN MARIANNA: DMJV Város Szociális Szolgálat - orbanmarcsu@gmail.com \\ TóTHNÉ GöRÖG EDIT: DMJV Város Szociális Szolgálat Nagysándor Telepi Gondozó Szolgálat \\ Kandia Utcai Demens Idősek Klubja - kandia4@dmjvvszsz.hu \\ NAGY LAJOSNÉ: DMJV Város Szociális Szolgálat - nagy.lajosne@dmjvvszsz.hu
}

ABSZTRAKT A tanulmány célja, hogy összegezze egy demenciával élő családtagjukat gondozók számára kialakított támogató csoport tapasztalatait. A csoport 2009-ben történt megalakulása óta általában havonta ült össze, egészen 2020 elejéig, a Covid-19 járvány kezdetéig. A kiscsoportként működő formáció strukturált gyakorlatok segítségével nyújtott érzelmi támogatást, információs és pszichológiai segítséget a családi gondozóknak. Az intézményes hátteret a DMJV VSzSz Kandia utcai nappali ellátási központja képezte, amely speciális gondozást és szolgáltatást nyújt a családi segítők idős hozzátartozói számára. A demenciával élő idősek számára memóriatréningek, realitás orientációs és szociális interaktivitást támogató gyakorlatok vannak kialakítva. A családi gondozók, köztük sok elsődleges gondozó, általában a gondozás feladataitól túlterhelten, olyan támogatásban részesülnek a csoporttól, amely védelmet nyújthat a kiégéstől és segít az erőforrásokkal való jobb gazdálkodásban.

A tanulmány kontextusába illeszkedik a kiégés föbb jellemzőinek anyaga, Gail Sheehy nyolc szakaszos állomáselmélete a családi segítők által bejárandó nehéz útról, és a Montgomery-Kosloski-féle Gondozói Identitás Elmélet.

Kulcsszavak: demencia szindróma; családi gondozók; kiégés prevenció; támogató csoport

\begin{abstract}
Support group for relatives who are caring for their family members living with dementia ABSTRACT The study aims to summarise the experiences with supportive groups designed for those, who care for family members living with dementia. The group founded in 2009 and it worked on a monthly basis until the beginning of 2020 when the Covid 19 pandemic started. The group worked as a small group with structured practices and provided emotional support, informational and psychological help for the family caregivers. The institutional basis is a day care centre of Urban Social Service of Debrecen which provides special care and service for elderly relatives of family caregivers. The practices used for elderly living with dementia include memory training, reality orientation and social interactions exercises. The family members, many of whom are primary caregivers, generally are overwhelmed by the burden of the caregiving and the support group protected them from the burning out and helped strengthen their resources. In the context of this study the main features of burned out, the model of Gail Sheehy which is connected to the serious eight-stage path taken by caregivers and the Caregiver Identity Theory by Montgomery-Kosloski are also discussed.
\end{abstract}

Keywords: dementia syndrome; family caregivers; burnout prevention; support group 


\section{BEVEZETÉS}

\section{A családi gondozók támogatásának szükségessége}

Alapvetése az idősekkel kapcsolatos gondozói törekvéseknek annak elősegítése, hogy ameddig lehetséges, az idős ember fenntarthassa függetlenségét, és ehhez ő és a családja minél nagyobb informális és formális támogatást kapjon, utóbbit az ellátó hálózatoktól.

A demencia, különösen annak leginkább elterjedt változata - az Alzheimer-kór - enyhe fokozatában még ad esélyt a vele birkózónak arra, hogy viszonylag önállóan éljen, de már ekkor is fokozott odafigyelést és időszakos felügyeletet igényel. A fokozatosan romló állapotokat produkáló, menthetetlenül egyre súlyosabbá váló, jelenleg még gyógyíthatatlan degenerativ betegség középsúlyos állapotában már nem ad lehetőséget az önállóság fenntartására. Agondozó családra nagy nyomás nehezedik, ugyanakkor a családi gondozást nyújtók jólléte összetett módon kapcsolódik a gondozásra szoruló idősek jóllétéhez. Gyakran a gondozó családtag nyújtja az elsődleges ellátást (primer gondozó) az idős, demenciában szenvedő hozzátartozó számára. Ebben az esetben, különösen a súlyos fokú demenciában szenvedők gondozásánál, a primer gondozókra olyan sok teher nehezedik, hogy náluk joggal beszélhetünk a szakirodalomban gyakran emlegetett „36 órás nap”-ról (Szabó 2011).

\section{A kiégés jelensége}

A kiégés jelenségének föbb jellemzőit azért tartjuk szükségesnek bemutatni, mert nem csak a professzionális segítőket, hanem a laikus gondozókat is veszélyezteti. A demenciában szenvedő hozzátartozókat gondozó családi segítők - különösen ha elsődleges segítők és kevés külső támogatást kapnak -, gyakran nagyobb kockázattal és eséllyel válnak kiégetté, mint a formális segítők.

A kiégés jelenségét először Herbert J. Freudenberger amerikai pszichoanalitikus figyelte meg és írta le 1974-ben. Tapasztalatai alapján önsegítő közösség tagjainál, krízisintervenciós központokban dolgozóknál, egészségügyben tevékenykedőknél jelentkeztek azok a tünetek, amelyek általában minden segítő foglalkozású szakembert veszélyeztethetnek. Értelmezése szerint a tünetek nyalábokba rendeződnek és tünetegyüttesként írhatók le (Fekete 1991).

Christina Maslach a humán szolgáltatásban dolgozók kiégésének mérésére kérdőívet alkotott $(\mathrm{MBI})$, amivel egyben a kiégés jelenségének három fő dimenzióját is operacionalizálta (Byrne 1991). Munkatársaival végzett nagy formátumú, mentálhigiénés szakembereket érintő kutatásai alapján úgy tekinti a kiégést, mint a munkavégzést akadályozó pszichikus állapotot, amelyet a nem megfelelően kezelt, nem feloldott munkahelyi stressz okoz, s amelyet érzelmi kimerültség, az emberi kapcsolatokban jelentkező fokozott elszemélytelenedés, elégedetlenség és borúlátás, a betegségekkel szembeni csökkent ellenállás és a nem hatékony munkavégzés jellemez (Herr - Cramer 1992).

A kiégés mint az emberi természet és pszichikum egyik megnyilvánulási formája, természetesen nemcsak a humán szolgáltatás területére korlátozódik. Minden tevékenység áldozatul eshet a kétségbeesésnek, kiábrándulásnak és végül az energia elapadásának. 
A probléma mégis a humán szolgáltatás területén jelentkezik rendszeresen. Ennek oka az, hogy a humán szolgáltatáshoz tartozó szakmák számos „beépített” frusztrációforrást rejtenek magukban. Ilyenek a teljesítménymérés kritériumainak a hiánya, az alacsony fizetések a képzettség, a jártasság és a felelősség minden szintjén, a hivatali ranglétrán való előrelépés és a klienssel való kapcsolat megszünésének dilemmája, a nemi alapon történő megkülönböztetés, a nem megfelelő anyagi és intézményi támogatás, a források eredménytelen felhasználása, a nagyfokú nyilvánosság népszerü félreértések és gyanakvások kíséretében. A kiégés egy folyamat, amelynek szakaszai a nagy reményekkel, energiával és irreális elvárásokkal jellemzett kezdeti periódus, amit a stagnálás szakasza követ, ahol a hangsúly a saját személyes igények kielégítésére esik, fontossá válik a pénz, a munkaidő és az előrejutás. A harmadik a frusztráltság periódusa, amikor az egyén megkérdőjelezi saját hatékonyságát és munkájának értékét. A negyedik a frusztrációval szembeni természetes védekezés, az apátia szakasza, amit a kihívások kerülése jellemez, az egyén a tevékenységére csak a minimálisan szükséges időt fordítja. A folyamat nem lineáris, számtalanszor megismételheti önmagát. Az egyént nem csak elkülönültségében érinti. Minden egyes fázisában és minden irányban terjed: személyzetről személyzetre, személyzetről ügyfélre és ügyfélről személyzetre. Ugyanakkor a kiégés folyamata egy döntő beavatkozással megállítható, enyhíthető (Barbócz 2005; Pék - Barbócz - Molnár 2007).

\section{A gondozó családtagok megküzdési stratégiái}

Jelen tanulmányunkban röviden bemutatjuk Gail Sheehy tizenhét évnyi személyes gondozási tapasztalatára és sok száz interjúra épülő, a családi gondozók megküzdésének nyolc fordulópontját azonosító modelljét (Szabó 2011: 147-150). Ebben a gondozó családtagok megküzdési stratégiáinak nyolc állomását különíti el. A folyamatot a labirintus metafora segítségével teszi szemléletessé. A családtagok „bolyongására”, a tragikus helyzetekkel való szembesüléseik élményvilágára utalva állapítja meg, hogy a bejárt út számukra olyan, mintha egy labirintusban keresnék a helyes irányt, ahol egy stáció, megoldás megtalálása után a leküzdöttnek vélt nehézség váratlanul ismét megjelenhet, vagy előbukkanhat egy újabb probléma. A modell megalkotóját egy templomban átélt spirituális élmény vezette el a labirintus metaforához, amikor az épület padlójába rajzolt spirál bejárása mentén a középpontba jutva észlelt intimitást, majd reményt, megnyugvást és elfogadást. Nem nehéz felfedezni, hogy a metafora egyetemesebb vallásos szimbólumrendszerre is utal, a kálváriák stációinak analógiájával szakrális szenvedéstörténetre, kapaszkodót találva az egyéni szenvedések érzelmi, lélektani feldolgozásához. Sheehy szerint gondozóként a „labirintuson” való haladás során rendet találhatunk a káosszal szemben, és a veszteségélmények feldolgozásával felülemelkedhetünk a tragikus nehézségeken, újra megtalálhatjuk önmagunkat. Természetesen ez egy spirituális utazás.

A fordulópontok felismerése, azonosítása, megértése tehát fontossá válik a betegséggel való küzdelemben. A stációk fókuszában azok a gondozás folyamán bekövetkező változások állnak, amelyek új megküzdési stratégia megtalálását, alkalmazását teszik szükségessé, olyan szempontváltásokat, amelyek újabb tárgyi eszközöket és lelki feltételeket, attitűdöket hívnak elő. Ebbe folyamatba kapcsolódik az ellátó rendszerek hozzáférhető szolgáltatásainak igénybe vétele is. 
Sheehy nyolc fordulópontot jelöl ki a gondozói erőfeszítések folyamatában:

1. Sokk és mobilizálódás.

2. Az új kerékvágás megtalálása

3. A bumeráng

4. Amikor a gondozó „Jóistent” játszik.

5. „Ezt nem tudom tovább csinálni.”

6. A visszatérés

7. A köztes fázis

8. A hosszú búcsú

Az állomások elnevezései önmagukban is jól érzékeltetik a küzdelmekkel teli út fordulópontjainál tapasztalt nehézségeket, az átélt élmények lényegi mozzanatait, így jelen dolgozatban ezeket nem bontjuk ki részletesebben.

\section{BÁLINT-CSOPORT MINT MÓDSZERTANI KERET}

A Bálint Mihály által a londoni Tavistock klinikán 1950-ben alapított, eredetileg orvosok számára kidolgozott csoportmódszer alapvetően háziorvosok pszichoterápiás továbbképzését szolgálta. Az alapvető elméleti keretet a pszichoszomatikus szemléletű gondolkodás nyújtotta. Az elmúlt évtizedekben a bálinti csoportmódszer alkalmazási területe lényegesen kibővült. A segítő foglalkozások, a gyógyító tevékenységek széles körét érintve világszerte terjedt a módszer. Minden olyan szakmai területen alkalmazhatóvá vált, ahol a kliensekkel való foglalkozás, segítő kapcsolat áll az előtérben. Jelenleg ilyen területek a pedagógiától kezdve a szociális munkán át az idősgondozáson keresztül a humán erőforrásokig körvonalazódnak. A módszert időközben megtermékenyítették, hatékonyabbá tették a csoportdinamikai, rendszerszemléleti elemek. A bálinti csoportmódszer nagyon jól hasznosítható a résztvevők professzionális, önismereti fejlődésének elősegítésére. A személyes szakmai erőforrások felmérésén, azonosításán, tudatosításán és fejlesztésén túl fontos megelőző, korrektív szerepet is játszhat a segítő foglalkozásúakat gyakran megérintő kiégési folyamatok kezelésében. Az általunk kialakított hozzátartozó csoport módszertani kereteként már csak azért is érvényes a bálinti megközelítés, mert a beteg hozzátartozóját hosszabb időn át, folyamatosan gondozó, ápoló családtag saját maga is előbb-utóbb kénytelen „professzionális” gondozóvá válni. Ebben az identitásában hasonló jellegü támogatást igényel és érdemel, mint azok a segítő foglalkozásúak, akik Bálint-csoportokban juthatnak pszichoterápiás keretben támogatáshoz, szakmai önismeretük fejlődéséhez, érzelmi megerősítéshez (Harrach - Schnell 2008).

\section{TAPASZTALATAINK DEMENCIÁVAL ÉLŐ CSALÁDTAGJUKAT GONDOZÓ HOZZÁTARTOZÓK SZÁMÁRA KIALAKÍTOTT TÁMOGATÓ CSOPORTTAL}

A DMJV Városi Szociális Szolgálat Nagysándor Telepi Gondozó Szolgálatának Kandia utcai demenciával élők számára kialakított Idősek Klubja 2008 óta napközi otthon jellegű tehermentesítő szolgáltatást nyújt demenciában szenvedő hozzátartozójukat gondozó családtagok számára a hét hat napján. A 2009-ben indított támogató csoport ehhez a szolgáltatáshoz kapcsolódóan indult és általában havi egy alkalommal megvalósuló, kiscsoportos formában 
történő összejövetelek keretében azóta is folyamatosan működik. Az összejöveteleket 2020 elejétől a Covid-19 betegséget okozó világméretű pandémia miatt kénytelenek voltunk szüneteltetni és valószínüsíthetően csak a 2021. év második felében kerülhet sor a csoport ismételt megszervezésére.

A csoportban általában azok a hozzátartozók vettek részt, akiknek demenciában szenvedő hozzátartozóik folyamatosan jártak az Idősek Klubjába. A klubban nyújtott nappali ellátás, gondozás, foglalkoztatás nagyfokú tehermentesítést jelent a gondozó családtagok részére, akiknek többsége elsődleges gondozóként állt beteg családtagja mellé.

A gondozottak többsége Alzheimer-típusú demenciában szenvedett. Saját tapasztalataink is megerősítették azt a szociális szférában ismert evidenciát, hogy a hozzátartozókat a technikai jellegü, gondozói ismereteket átadó, informáló, tanácsadó segítség mellett szükséges érzelmi, lelki támogatásban is részesíteni.

A támogató csoport félig strukturált gyakorlatokkal, tematikus beszélgetésekkel „Bálintcsoport" jelleggel müködött. A 15 főnél nem nagyobb csoportlétszám lehetővé tette a kiscsoportos dinamika kibontakozását. A csoportfoglalkozások minimum másfél, maximum 2 órás időkeretben folytak. A kiscsoportban formálódó kommunikáció lehetőséget adott minden résztvevő számára a nyitókörben az adott ülésre hozott saját probléma, többnyire ápolási, gondozási teher felvetésére, az aznapi foglalkozással kapcsolatos elvárások megfogalmazására. Ugyanakkor a zárókör lehetőséget adott mindenki számára a csoportülés végén az aznapi élményekkel, tapasztalatokkal kapcsolatos reflexiók, önreflexiók megfogalmazására. Ezen keretezések körbefonták a legégetőbb, legjobban aktualizálható témák megjelenítését, a legnagyobb szenvedésnyomásnak kitett csoporttagok gondjainak előhozatalát, megbeszélését. Amellett, hogy a nyitó- és zárókör lehetőséget adott minden résztvevőnek egyfajta elvárt, felkínált szóbeli megnyilvánulásra, az adott csoportülések dinamikája és történései természetesen egyediek, az „itt és most”-ban történők voltak, ezek gyakran felkavaró érzelmi megnyilvánulásaival. A konfliktusok elsősorban az elhatalmasodó degeneratív betegséggel, a családra kimért, a sors kíméletlenségével, a betegek állapotában tapasztalható tragikus fordulatokkal, a megtapasztalt testi és mentális romlással kapcsolatban és kevésbé a csoporttagok közötti ellentétekben, rivalizálásban jelentkeztek. Egyben állandó kihívást jelentett a gondozottakkal kapcsolatos „harc”, a küzdelem a mindennapi életvitel elviselhetővé tételéért, amely során maga a beteg egyre kevésbé „normális” viselkedése jelenti a legnagyobb frusztrációt. A család megszokott működése jóvátehetetlenül megváltozik, már sok minden nem mehet a „régi” kerékvágásban, a hétköznapi értelemben vett gyógyulás nem remélheto”. A csoport „jó” működése akkor vált még egyértelmübbé, amikor éppen a gondozottakkal kapcsolatos ellenérzések, negatív érzelmek, agresszív fantáziákról vagy indulatos magatartásról szóló beszámolók is előkerülhettek. A sors és a betegség helyett magára a betegre is áttevődhetnek a negatív érzések, amelyek keverednek a szánalom, veszteség, a megváltoztathatatlanság érzelmeivel.

A csoporttagok megkönnyebbülten tapasztalhatták, hogy nincsenek a "jó viselkedés" kényszere alatt, a csoport megengedő légköre lehetőséget ad a negatívnak tartott érzelmek megnyilvánulására is. Mivel a gyógyulás nem elérhető, a csoporttagok betegséghez kapcsolódó attitűdjeinek átalakulásától várható jobbító változás, ami elvezethet az elfogadáshoz, nagyobb belátáshoz, megnyugváshoz. Ugyanakkor az az út nem minden hozzátartozó számára járható, nem mindenki tud eljutni az elfogadás és megnyugvás felszabadító érzéseihez. A cso- 
portvezetők igyekeztek a gondozókat életminőségük javításának szükségességére figyelmeztetni, az öngondoskodás és a rekreáció fontosságát tudatosítani.

A Bálint-csoport módszertani kerete lehetőséget ad a csoporttagok számára, hogy visszajelzéseket és támogatást kapjanak saját segítői, gondozói készségeik optimalizálásához. A csoportmunka révén felszínre kerülhet a gondozó által tudatosan nem észlelt kapcsolati, érzelmi zavar vagy gátló tényező is. A bálinti keret a gondozó hozzátartozók kiégésének csökkentéséhez és az erőforrások optimalizálásához is jó lehetőséget nyújt.

\section{A CSOPORTVEZETÉS JELLEGE ÉS A TÖRTÉNÉSEK DIMENZIÓI}

A tapasztalatok megerősítik, hogy a támogató csoportok vezetése kiemelt szakmai feladat, kiérlelt csoportvezetői tapasztalatokat, csoportdinamikai ismereteket és ezek hatékony alkalmazásának készségeit kívánja meg. Ezért nem javasolható, hogy laikus segítő vagy hasonló helyzetben lévő sorstárs - akár sokrétű gondozási tapasztalatokkal felvértezve - vállalja a hozzátartozó támogató csoportok irányítását. A kettős vezetéssel szerzett tapasztalataink arra mutatnak, hogy egy csoportdinamikai ismeretekkel és tapasztalattal rendelkező szakember jelen esetben klinikai szakpszichológus - és egy szintén képzett vezető szakápoló, szociális gondozó, mentálhigiénésen képzett szakember együttműködése gyümölcsöző lehet.

A bemutatott csoport létrejöttét és folyamatosságának fenntartását alapvetően meghatározta, hogy az egy demenciával élők számára kialakított napközi otthon, klubszerű nappali ellátási forma müködéséhez szorosan kapcsolódott. A párhuzamosság lehetővé tette, hogy intézményi térben, a gondozottak helyiségei melletti szobában történjenek a csoportülések. A társvezetői helyzetben lévő gyakorlati szakember, aki a gondozói, foglalkoztatói munkában is részt vett, folyamatosan adott át információkat a betegek napközbeni társas megnyilvánulásairól, viselkedéséről. Az otthoni helyzetet megjelenítő gondozó családtag az érzelmeket sokszor drámai módon közvetítő beszámolói és a professzionális segítők által hozott információk, közlések kereszt- és hosszmetszetben is leképezték a történteket, érzékeltetve azok dinamikáját, visszatérő narrációit. Valójában három észlelhető, jól körülírható tapasztalati dimenzió találkozása révén zajlottak a csoport nyíltabb tranzakciói, kommunikációs mozzanatai, érzelmi megnyilvánulásai. Természetesen mindezeket a csoporttagok egyéni megnyilvánulásai, érzelmei, narrációi tovább szőtték, interaktivitásukkal egyedivé téve minden csoportülést.

\section{STRUKTURÁLT GYAKORLATOK A HOZZÁTARTOZÓI CSOPORTBAN}

Az alábbiakban bemutatunk pár módszert a repertoárunkból, amelyeket hatékonynak tartunk:

Érzelmileg fontos fotók bemutatása az egészséges élet emlékeiként, fontos érzelmek hordozóiként alkalmasak a „normális” élet kisebb-nagyobb eseményeinek felidézésére, a pozitív érzelmek ismételt átélésére, átmentésükre a gondozás nehéz életszakaszába.

Kisebb személyes tárgyi emlékek, a hozzájuk kapcsolható történetek, narrációk hordozói. Bemutatásuk, a történetek kibontása mentén rekonstruálhatóak a közös múlt szegmensei. 
Egy-egy tárgy, például egy pipa, levélnehezék, vagy kedvenc kisplasztika a beteg szokásainak, kötődéseinek megelevenítését szolgálhatja, egyben magát a beteget „pars pro toto” jelleggel, szimbolikusan is megjelenítheti.

Egy olyan kéréssel is fordultunk a hozzátartozókhoz, hogy írják meg a gondozott családtag önéletrajzát magának a gondozottnak a nevében, mintha ezt ő fogalmazná, és betegsége súlyosabbra fordulásától hosszabbítsák ezt meg, írják le életének lehetséges egészséges folytatását. A múlt, jelen és egy lehetséges „mintha” jövő együttes konstruálása egyrészt lehetővé teszi a múlt történéseinek, a szeretett személy élete főbb állomásainak, eredményeinek számbavételét, elismerését, közös emlékek felidézését. Az életrajzokban megvalósuló rekonstrukciók egy ép, egészséges, „normális” élet narratíváit is megidézhetik, amelyeket a csoporttagok a megbeszélések folyamán egymással is megoszthatnak. A beteg lehetséges egészséges életének „mintha” jelleggel való felépítése, képzeletbeli meghosszabbítása természetesen megrázó szembesülést is eredményezhet. Egyben az ezekkel kapcsolatos érzések megfogalmazásai átvezethetők a gondozók saját életének, ennek jelentőségének átgondolásához, megbecsüléséhez, annak megóvása, továbbvitele szükségességéhez. Ezeknek az önéletrajzoknak észlelhetően nagy érzelmi megmozgató ereje, pozitív megerősítő hatása volt, és elvezettek a gondozói életminőség javításának, a rekreációk elengedhetetlen szükségességének, a saját mentálhigiéné fontosságának témáihoz is.

A „nehéz kő” gyakorlathoz egy ovális, koponyaformájú, 5 kg súlyú, vulkáni eredetű kő adta a materiális fogódzkodót. A gyakorlat során a követ kézről kézre adták a csoporttagok, amelyet ölben tartottak, megemeltek és egy ideig támaszték nélkül tartottak. A „ceremónia” szerint mind az átvétel, tartás, megemelés, átadás mozzanataira koncentráltak és az instrukció szerint szabadon asszociálhattak, engedtek gondolataik és érzelmeik áramlásának. Természetesen az asszociációk áramlása szorosan kapcsolódott az adott gondozói helyzethez, behozta a nyomasztó megterhelések, de azok elengedési, könnyítési lehetőségeinek a témaköreit is. Fontos gesztusnak bizonyult a kő/teher átadásának gesztusa, ami a tehermentesítési stratégiákkal került analógiás kapcsolatba. A gyakorlat több résztvevőnél is heves érzelmeket, katartikus hatást váltott ki.

\section{A CSALÁDI ÉS A GONDOZÓI IDENTITÁS FESZÜLTSÉGE}

A tanulmányunkban is bemutatásra kerülő Montgomery-Kosloski-modell megbeszélése révén a csoporttagok számára is szemléletes, gyakorlatias formában tudatosul a családtag szerep és a gondozói szerep közötti identitásváltás felismerésének fontossága. A modellhez kapcsolódhattak a személyes, egyedi tapasztalatok és ezek átgondolása segített a gondozói identitás megerősítésében, a családtag identitás fenntartásában. A két identitás közötti egyensúly megtartása különösen akkor kerül veszélybe, amikor a degeneratív betegség olyan mértékü romlást visz végbe a beteg kognitív funkcióiban, hogy annak memóriarendszerei már nem képesek fenntartani a saját identitáshoz szükséges önmagára vonatkozó emlékeket. Ez a folyamat összekapcsolódik azzal, hogy a beteg már saját családtagjai felismerésére sem képes.

Ezek a mentális állapotban bekövetkező romlások különösen megterhelővé teszik a beteg családtag gondozását, a vele való kommunikációt és mindkét részről a családtag identitás fenntartását. A Montgomery-Kosloski-modell annak belátásához is támpontot nyújt, hogy 
egy bentlakásos intézeti elhelyezés - amelynek igénybe vételétől éppen a hősiesen kitartó gondozó hozzátartozók igyekeznek távol tartani magukat - segíthet a családtagi identitás bizonyos fokú helyreállításában. Ebben az esetben a családtagot nem „szippantja” teljesen be a gondozói erőfeszítésekből adódó szerep.

\section{MONTGOMERY ÉS KOSLOSKI ÖTFÁZISÚ GONDOZÁSI MODELLJE: A GONDOZÓ CSALÁDTAG IDENTITÁSVÁLTOZÁSÁNAK FOLYAMATA}

Az Alzheimer-kórban szenvedőkre jellemző pszichikus állapot főbb jellemzői a bűntudat, önmaga meghatározásának zavara, félelem, és egy idő után annak hiánya, hogy ki is ő valójában. Kapcsolataiban szeretetigénye és annak kielégítetlensége bizonytalanná teszi. Ennek a folyamatnak a tükörképével találkozhatunk az elsődleges gondozó családtag vonatkozásában is. A gondozó családtag is átéli a bűntudatot, a félelmet, önmaga meghatározásának zavarát abban, hogy egy idő után ki is ő a gondozott családtagja számára. Kapcsolataiban szeretetigénye és annak kielégítetlensége őt is bizonytalanná teszi.

Montgomery és Kosloski (2009 és 2013) nevéhez füződik a gondozó családtag identitásváltozásának folyamatát leíró modell, amelyet egy előző publikációban már részben bemutattunk (Pék 2013). A modellben a szerzők öt jól körülírható és követhető fázist különítenek el, és dinamikus folyamatnak tekintik azt a változást, amely során a családtag identitást fokozatosan felváltja, kiszorítja a gondozói identitás. Ezt a folyamatot jelentősen meghatározza a gondozott funkcionális állapotának fokozatos romlása, ápolási szükségletének egyre nagyobb arányú növekedése. Az előbbiek olyan nagy hatást gyakorolnak a gondozó és gondozott közötti kapcsolatra, hogy előidézik a családi rendszer gyökeres átalakulását és ezek nyomán kialakul a családi gondozó identitásváltozása.

Az első fázisban a családi gondozás közegében az ápolási szükségletek nyomására kialakuló gondozói identitás az adott, már kialakult és megszilárdult családi szerepekből adódó megszokott identitástól különválik. A család müködésében jól azonosítható szerepekből - mint amilyen a lány, feleség, férj - emelkedik ki a gondozói szerep.

Az Alzheimer-betegség korai fázisában jelentkező feledékenységgel és tájékozódási zavarral szembesülő hozzátartozó - jelen példánkban a megbetegedő anya leánya - fokozott gondoskodással reagál, segítséget nyújt a napi feladatok és szociális aktivitások megszervezésében, lebonyolításában. Ebben az első fázisban még nem jelenik meg gondozói identitásváltás, a lány már fokozottan gondoskodóvá válik, de mindezt még „családtag” identitással végzi.

A második fázisban már jellemzően tudatosodik a lányban, hogy gondozási aktivitása már a „normális” határon túllépett mind mennyiségben, mind minőségben. Ugyanakkor még megmarad az alapvető családtagi („A lánya vagyok anyámnak”) identitás anyjával kapcsolatban a gondozó-gondozott viszonylatban, amihez viszont már a gondozói szerep egyre markánsabban kapcsolódik („Lányaként sokat segítek anyámnak”).

A harmadik fázisban a gondozott állapota alapvetően romlik a degeneratív betegség elörehaladtával. Gondozási szükségletei már jóval túl vannak azon a határon, ami egy „normális” családi helyzetben elfogadható lenne. Ettől a ponttól kezdve, amikor a családtag szerep fölé emelkedik a gondozói szerep, egyre jobban elnyomja, háttérbe szorítja az előbbit, és a gondozói szerep kezd a gondozottal kapcsolatban meghatározóvá válni. Mindez az ápolói identitás 
megszilárdulásához vezet („Sokkal inkább vagyok az ápolója demenciában szenvedő, egyre magatehetetlenebb anyámnak, mint a lánya"). Ebben a fázisban kezd el a hozzátartozó egyre jobban foglalkozni külső, professzionális segítség, ellátás elfogadásával, vagy idősotthoni elhelyezéssel.

A negyedik fázisban a gondozó még többet foglalkozik a gondozott idősotthoni elhelyezésének lehetőségével. Ebben a fázisban a gondozói identitás már egyértelműen a családtag identitás fölé kerekedik, elnyomva azt, nyomasztóan elsődlegessé válva.

Az ötödikfázisban már teljes a gondozói identitás dominanciája. Ekkorra a családtag szerep és identitás teljesen háttérbe szorul. A gondozott családtaggal való kapcsolatot már az ápolási aktivitás uralja („Már csak az ápolója vagyok annak, aki az anyám volt valaha”).

A súlyos fokú demenciában szenvedő beteg ilyenkor többnyire már képtelen a családtagok felismerésére, azonosítására. Elveszti orientációs képességét térben és időben, saját identitását is „elfelejti”. Énje, személyisége szétesik. Gyakran ebben a fázisban következik be vagy egy másik gondozó családtagnál, vagy idős otthonban, elme-szociális otthonban történő elhelyezés. Ez a tehermentesítés teszi lehetővé a gondozó családtag számára, hogy visszatérjen a családi identitásához és képes legyen arra, hogy a gondozott hozzátartozóval való viszonylatában elsődlegesen újra családtagként határozza meg magát. Gyakori, hogy ismételten kialakul a második fázisra jellemző identitásviszony.

A Montgomery-Kosloski-modell alkalmas arra, hogy segítő szakemberek - szociális munkások, pszichológusok, trénerek, tanácsadók - számára a gondozó családtag támogatásában, annak gyakorlata kidolgozásában támpontokat, segítséget nyújtson.

\section{ESETPÉLDÁK A HOZZÁTARTOZÓI CSOPORTBÓL}

(Az itt szereplő keresztnevek nem azonosak a bemutatott csoporttagok keresztnevével)

\section{Géza története}

Általában a gondozói tevékenységeket, az ellátás zömét biztosító hozzátartozó, az elsődleges (primer) gondozó nő, akit szükség esetén a családban általában szintén női családtag vált.

Géza feleségét gondozza, aki hosszú évek óta szenved Alzheimer-típusú demenciában.

Felesége a degeneratív betegség súlyos fázisában van, a nap 24 órájában gondozásra szorul.

Az éjszakák és a nappalok is megterhelőek, mert a beteg alapszükségleteit sem tudja egyedül végezni, evésben, ivásban, öltözködésben, tisztálkodásban, szükségletei elvégzésében segítségre szorul. Géza gyakorlatilag egyedül, csekély otthoni segítséggel végzi hősies munkáját. Amikor a csoporttalálkozókon szóba jön a tartós intézeti elhelyezés, elveti ennek lehetőségét, annak ellenére, hogy eröforrásai - saját észlelése szerint is - kezdenek kimerülni.

Többször is megfogalmazza, hogy a Kandia utcai gondozó szolgálat napközi otthonos ellátása nélkül nem bírná a megterheléseket. A csoport szinte az egyetlen lehetősége az otthonán kívüli társas együttlétre, a napközbeni tehermentesítés ad számára alkalmakat ügyeinek intézésére, bevásárlásra. A csoportfolyamatban „törzstagként” saját tapasztalatait rendszeresen átadja a résztvevőknek, egy olyan hiteles gondozói narratívát megosztva, amely a megpróbáltatások szenvedésterhét egyrészt megjeleníti, a betegség progressziójának állomásait nem titkolva, másrészt helytállásból, példaadásból is viselkedési mintát nyújt a többieknek. Az érzelmi többlet átadásán túl, amely az odaadó, egyben szenvedéssel teli gondozói „karrier” be- 
mutatásánál is megnyilvánul, Géza a realitás kontrollt is képviseli a csoporttagok számára. Többek között azzal a többször is visszatérő figyelmeztetéssel, hogy a beteg hozzátartozóknál észlelt - sajnos csak átmeneti - jobb állapotot ne értékeljék tartós javulásként, ne gondolják azt, hogy ezek a reményteljes állapotok elveszett készségek teljes rekonstruálását jelentik, ne lépjenek „tanítói” vagy „tréneri” szerepbe, fejlődési ívben reménykedve.

\section{Réka esete}

Ő is „törzstagunkká” vált, az első években vett részt a csoportban, egészen az általa gondozott férje haláláig. Értelmiségi férje betegségéhez kezdettől fogva nagy optimizmussal és elkötelezettséggel viszonyult. Aktivitása és kezdeményezőkészsége pozitív energiákat adott a csoportnak is. Nyitott volt a szerepjátékokra és a témák dramatikus eszközökkel való bemutatására, és alkalmanként konferencián is vállalta a gondozási, ápolási tapasztalatainak közvetlen megosztását. Érdeklődő, támogató, empatikus viszonyulásával egyrészt modellt nyújtott a csoporttagoknak, másrészt mobilizálta is őket. Segítette a többieket a realitás felé orientálódni az Alzheimer-betegség elkerülhetetlen progressziójával való megküzdésben. Számára férje betegsége mint kihívás jelent meg és ez a családjával való még szorosabb együttműködéshez vezetett. Jó példáját adta annak az összefogásnak, amikor egy család a betegséggel való megküzdésben az érintett családtag és egymás segítésében az optimumon működik. Erőfeszítéseik közepette sem hiányzott mindennapjaikból a jókedv és a sokszor gyötrelmeket okozó megterhelések fölé emelkedés igyekezete. „Mindenbe belevisszük a humort és a játékosságot” hangzott el többször is egyik mottójuk. Mindezekből adódóan a családi színterük nem egy „elfekvő” részlegként, hanem saját magát is regenerálni képes rendszerként funkcionált.

\section{Mária bemutatkozása}

Egy alkalommal jelent meg a csoportban, ahová szinte megállíthatatlan panaszáradattal, keserüséggel és értetlenséggel érkezett. A csoport tapasztaltabb, „bölcsebb” és a demencia szindrómából következő nehézségeket már jobban ismerő és ezeket már elfogadhatóbban kezelő tagjainak pozitív szuggesztiói, megértő támogatása ellenére nehezen csillapodott.

Valójában magatartásával, érzelmi reakcióival is megjelenítette, átadta, érzékelhetően eljátszotta demenciában szenvedő édesanyja értetlenségét, helyzetük elviselhetetlenségét.

A csoport „gyógyító” tagjai megnyilvánulásaikkal próbálták ellensúlyozni, enyhíteni Mária negatív érzelmeinek áradását, de ő ebben a helyzetében képtelen volt a segítséget elfogadni és bár bíztunk abban, hogy a ventilláció, a fájó érzéseknek, keserüségnek a megfogalmazása segíthet, könnyíthet, többé nem jelent meg a csoportfoglalkozáson.

\section{Rózsika egy másik kultúrából}

Idősebb asszonyként Erdélyből érkezett és az anyai elfogadás, gondoskodás, ápolási készség kulturálisan is más alapozottságú viszonyulását képviselte. Pár alkalommal tudott csak részt venni a csoportban, debreceni gondozottjának ápolásáról való beszámolója alapján hitelesen formázta meg a megértés, és alkalmasint a belenyugvó lemondás spirituális háttérrel is támogatott gondozói gyakorlatát. A csoportban megnyugtatóan hatott a jelenléte és pozitív érzelmeket és reményt sugárzó magatartása. 


\section{A TÁRSADALMI SZINTÜ TUDATOSÍTÁS SZÜKSÉGESSÉGE: KITEKINTÉS}

A bemutatott hozzátartozói csoport részben párhuzamosan zajlott az általunk 2007 januárjában megindított debreceni Alzheimer Caféval és a résztvevők alkalmanként mindkét formációban részt vettek. Dolgozatunk végén röviden utalunk azokra a társadalmi szinten zajló kezdeményezésekre, történésekre, amelyek a demencia tudatos közösségek megteremtésére irányulnak.

A demencia szindrómával kapcsolatban kialakult és elterjedt hazánkban is az Alzheimer Café mozgalom. Magyarországon dr. Menyhárt Lajos 2014-ben indította az első Alzheimer Café-t a strasbourgi, nemzetközi hírü Marc Berthel geriáter professzor ösztönzésére. Azóta ez a formáció országszerte elterjedt. A rendszeresen megtartott klubfoglalkozások folyamán az Alzheimer-kórban vagy a demencia szindróma más formáiban szenvedőket és családtagjaikat segítik. A kávézási alkalmak nyitottak minden érdeklődő számára, akik többet akarnak megtudni az időskori szellemi leépülés tüneteiről, azok enyhítéséről, vagy segíteni szeretnék az ismeretségi körükben lévő betegeket. 2018. április 26-án Budapesten, a Csokonai Művelődési Házban, az Alzheimer Cafék I. Országos Találkozóján a szakmai konferencia után a szervezők felhívással fordultak az ország különböző településeiről érkezett résztvevőkhöz egy országos séta megszervezése érdekében, amit szeptemberre, az Alzheimer Világhónapra időzítettek. Az Alzheimer Cafék szervezőinek köszönhetően az ország több pontján mintegy harminc település csatlakozott a kezdeményezéshez. A séta mellett számos, a demenciával foglalkozó szakmai rendezvényt is tartottak. A séta szlogenje a „Nem vagy egyedül!” elterjedt, és máig is hatékonyan szerepel különböző, hasonló célú rendezvényeken.

Radvánszki Edit és Jobbágy Mária nevét is érdemes megemlíteni, mert a senior örömtánc mozgalom és az Alzheimer Café formáció összekapcsolásával létrehozták a „Táncoljunk együtt a demenciával élőkért!" elnevezésű országos aktivitást (Jobbágy és Radvánszki, 2020).

A pandémia alatt az Alzheimer Cafék müködése vagy szünetelt, vagy online formában valósult meg, ami nehezen felülírható frusztrációt jelentett a szervezőknek, a hozzátartozóknak, az érdeklődőknek egyaránt.

Magyarországon számos film is fókuszál a demencia szindrómával kapcsolatos történésekre, részben dokumentarista, részben játékfilm müfajban. Színpadi feldolgozás is készült és számos fórum egyre többször jeleníti meg a betegséget, amely a média különböző szegmenseiben is gyakrabban, de még mindig nem optimális gyakorisággal szerepel.

Jelen tanulmányban ezeknek az örvendetes folyamatoknak a további részleteit nem tárgyaljuk, jelentőségük és szerepük kiterjedtebb bemutatást, értékelést igényel és érdemel.

\section{IRODALOM}

Barbócz, I. (2005): A kiégéshez vezető okok, a kiégés és megelőzésének lehetőségei a Családvédelmi Szolgálatot ellátó védőnők körében. Diplomamunka. Debrecen: DE Orvos és Egészségtudományi Centrum, Népegészségügyi Iskola

Byrne, B. M. (1991): The Maslach Burnout Inventory. Validating factorial structure and invariance across intermediate, secondary and university educators. Multivariate Behavioral Research Vol. (26)4: 483-505. https://doi.org/10.1207/s15327906mbr2604_2 
Fekete, S. (1991): Segítő foglalkozások kockázatai - Helfer-szindróma és burnout jelenség. Psychiatriai Hungarica, (6)1: 17-29.

Harrach, A. - Schnell, E. (2008): Bálint-csoport és a bálinti szemlélet az orvoslásban. Medicus Universalis, (43)3: 107-111.

Herr E. L. - Cramer S. H. (1992): Career Guidance and Counseling Thoough the Life Span: Systematic approaches (4th ed.) New York: Harper Collins Publishers.

Jobbágy, M. - Radvánszki, E. (2020): Táncoljunk együtt a demenciával élőkért! Szociálpolitikai Tükör, (82)3-4: 149-162.

Montgomery, R. J. V. - Kosloski, K. (2009): Caregiving as a process of changing identity: Implications for caregiver support. Generations, (33)1: 47-52.

Montgomery, R. J. V. - Kosloski, K. (2013): Pathways to caregiver identity and implications for support services. In: R. C. Talley - R. J. V. Montgomery (eds.): Caregiving across the life span: Research practice and policy New York: NY: Springer Publishing Company, 131-156. https://doi.org/10.1007/978-1-4614-5553-0_8

Pék, Gy. - Barbócz, I. - Molnár, P. (2007): Study on burnout phenomenon among Hungarian health visitor nurses of Family Protective Services. International Journal of Rehabilitation Research, (30) Suppl. 1, 70-71.

Pék, Gy. (2013): Speciális kommunikációs és gondozási szükségletek az időskori kétnyelvűséggel és idős családtagok gondozásával kapcsolatban. In: Kállai, J. - Kaszás B. - Tiringer I. (szerk.): Az időskorúak egészségpszichológiája. Egyetemi tankönyv. Budapest: Medicina Könyvkiadó Zrt., 289-302.

Szabó, L. (2011): Időskori demenciák családi, társadalmi és pszichológiai vonatkozásai. Pszi Könyvek. Budapest: Akadémiai Kiadó. 